\title{
Omentum flap as a salvage procedure in deep sternal wound infection
}

This article was published in the following Dove Press journal:

Therapeutics and Clinical Risk Management

9 November 2017

Number of times this article has been viewed

\section{Franjo Rudman' \\ Davor Barić2 \\ Daniel Unić2 \\ 'Department of Plastic, Reconstructive and Aesthetic Surgery, University Hospital "Dubrava", ${ }^{2}$ Department of Cardiac and Transplant Surgery, University Hospital "Dubrava", Zagreb, Croatia}

Correspondence: Franjo Rudman Department of Plastic, Reconstructive and Aesthetic Surgery, University Hospital "Dubrava", Avenija Gojka Šuška 6, 10000 Zagreb, Croatia Emailfrudman@dr.com

\section{Dear editor}

We read with great interest the report by Dr Spindler and coworkers about the utilization of omentoplasty as salvage procedure in deep sternal wound infection. ${ }^{1}$ First of all, we congratulate the authors on the excellent results. Mortality rates in this high-risk cohort of patients can be attributed to advanced age, comorbidities, and other complications, but neither the timing nor the type of reconstruction performed.

It is not clear whether omentoplasty was performed after average 60 days due to late infection onset or patient's poor medical condition. Complete mobilization of omentum is sometimes necessary because there is an abundant amount of omentum to cover the whole sternal defect, and the upper one-third of a sternal defect can be additionally covered with pectoral flaps over the underlying omental flap. We agree that the high rate of hernia formation is the most common complication, but in a life-saving setting, it can be tolerated. Laparoscopic flap harvest is of limited use, especially in cardiac patients, due to hemodynamic changes that pneumoperitoneum can trigger.

The initial treatment of mediastinitis should be debridement and application of topical negative pressure wound therapy, preferably with irrigation, for a few days, followed by additional debridement and reconstruction. Such treatment sequence provides better survival. ${ }^{2,3}$ Morisaki et al report that the best survival is achieved with initial treatment with topical negative pressure followed by the reconstruction with flap. ${ }^{4}$

We have routinely utilized latissimus dorsi flap in breast reconstruction, but it would not be the first choice for sternal reconstruction. Technical issues over patient positioning in 1-stage reconstruction led us to reserve its use for patients in whom we either have no other options or other options have been previously exercised. Pectoralis major flap, either as rotatory advancement flap or turnover flap represents our first choice for sternal reconstruction.

We utilize omental flap after partial (lower third) or complete sternal resection to cover the mediastinum and fill the sternal defect, and reduce the possibility of sternal reinfection. Omental flap is useful in reconstruction due to its immunologic properties, it can fill the deepest recesses and large defects and is considered to be superior to muscle flaps, especially for lower third of sternum, or the whole sternum with good stability of thorax..$^{5}$ Therefore, omental flap is very useful, if not, irreplaceable in certain indications of sternal reconstruction, most notably after resection of the lower third of the sternum.

\section{Disclosure}

The authors report no conflicts of interest in this communication. 


\section{References}

1. Spindler N, Etz CD, Misfeld M, Josten C, Mohr FW, Langer S. Omentum flap as a salvage procedure in deep sternal wound infection. Ther Clin Risk Manag. 2017;13:1077-1083.

2. Baillot R, Cloutier D, Montalin L, et al. Impact of deep sternal wound infection management with vacuum-assisted closure therapy followed by sternal osteosynthesis: a 15-year review of 23,499 sternotomies. Eur J Cardiothorac Surg. 2010;37(4):880-887.

3. Cotogni P, Barbero C, Rinaldi M. Deep sternal wound infection after cardiac surgery: evidences and controversies. World J Crit Care Med. 2015;4(4):265-273.

4. Morisaki A, Hosono M, Murakami T, et al. Effect of negative pressure wound therapy followed by tissue flaps for deep sternal wound infection after cardiovascular surgery: propensity score matching analysis. Interact Cardiovasc Thorac Surg. 2016;23(3):397-402.

5. Hultman CS, Culbertson JH, Jones GE, et al. Thoracic reconstruction with the omentum: indications, complications, and results. Ann Plast Surg. 2001;46(3):242-249. 


\section{Authors' reply \\ Nick Spindler' \\ Christian D Etz ${ }^{2}$ \\ Martin Misfeld ${ }^{2}$ \\ Christoph Josten' \\ Friedrich-Wilhelm Mohr ${ }^{2}$ \\ Stefan Langer'}

'Department of Orthopedic Surgery, Traumatology and Plastic Surgery, University Hospital Leipzig, ${ }^{2}$ Department of Cardiac Surgery, Leipzig Heart Center, University of Leipzig, Leipzig, Germany

Correspondence: Nick Spindler

Department of Orthopedic Surgery, Traumatology and Plastic Surgery, University Hospital Leipzig, Liebigstrasse 20, 04103 Leipzig, Germany

Tel +4934 I 97I 7|40

Fax +49 34I 97I 7139

Email nick.spindler@medizin.uni-leipzig.de

\section{Dear editor}

With great interest, we have taken into account the annotations to our article "Omentum flap as a salvage procedure in deep sternal wound infection."

We agree in great parts with the given remarks, as they summarize nicely our main statements expressed in the referred publication.

However, existence of a deep sternal wound infection (DSWI) was diagnosed on average 31 days following the initial cardiac operation, hereby fulfilling the premises for Type 2 classification of Pairolero. ${ }^{1}$ Due to the poor medical condition of the patients, they were apriori treated by the cardiac surgeons, and after stabilization of their health condition, presented to our division for reconstruction.

In our population, we indicated the omentum flap as a salvage procedure for therapy refractory DSWI mainly caused by superinfected non-removable artificial material. As stated by Hultman et al, we generally do not prefer the omentum flap as a first-line solution. ${ }^{2}$

Nowadays, the portfolio of the plastic surgeon contains a wide spectrum of pedicled and free muscle, as well as myocutaneous flaps. ${ }^{3-6}$
However, due to our patients' long stay in an intensive care unit, the pectoralis major muscle shows a relatively more intense atrophy than the naturally larger and more voluminous latissimus dorsi muscle. A safe coverage of the lower third of the sternum is hereby also in bi-lateral use only hardly possible. We furthermore see an average skin defect in the sternal region of $6 \mathrm{~cm}$ width caused by retracted skin borders. A primary closure would, therefore, put too much tension on the wound. The recommended and well-established pectoralis muscle flap is, therefore, not our first choice for reconstruction following DSWI.

The myocutaneous latissimus dorsi flap allows a voluminous filling of the dead space in the mediastinal region and makes sufficient coverage throughout the entire length of the sternum possible, especially in the lower third. The skin island averages $18.6 \times 5.8 \mathrm{~cm}$ in size and promotes a tensionless wound closure.

\section{Disclosure}

The authors report no conflicts of interest in this communication.

\section{References}

1. Pairolero PC, Arnold PG, Harris JB. Long-term results of pectoralis major muscle transposition for infected sternotomy wounds. Ann Surg 1991;213(6):583-589; discussion 589-590.

2. Hultman CS, Carlson GW, Losken A, et al. Utility of the omentum in the reconstruction of complex extraperitoneal wounds and defects: donor-site complications in 135 patients from 1975 to 2000. Ann Surg. 2002;235(6):782-795.

3. Beier JP, Arkudas A, Lang W, Weyand M, Horch RE. [Sternal osteomyelitis - Surgical treatment concepts]. Chirurg. 2016;87(6): 537-550. German.

4. Taeger CD, Horch RE, Arkudas A, et al. Combined free flaps with arteriovenous loops for reconstruction of extensive thoracic defects after sternal osteomyelitis. Microsurgery. 2016;36(2):121-127.

5. Spindler N, Lehmann S, Steinau HU, Mohr FW, Langer S. [Complication management after interventions on thoracic organs: deep sternal wound infections]. Chirurg. 2015;86(3):228-233. German.

6. Jurkiewicz MJ, Bostwick J 3rd, Hester TR, Bishop JB, Craver J. Infected median sternotomy wound. Successful treatment by muscle flaps. Ann Surg. 1980;191(6):738-744.

Dove Medical Press encourages responsible, free and frank academic debate. The content of the Therapeutics and Clinical Risk Management 'letters to the editor' section does not necessarily represent the views of Dove Medical Press, its officers, agents, employees, related entities or the Therapeutics and Clinical Risk Management editors. While all reasonable steps have been taken to confirm the content of each letter, Dove Medical Press accepts no liability in respect of the content of any letter, nor is it responsible for the content and accuracy of any letter to the editor.

\section{Publish your work in this journal}

Therapeutics and Clinical Risk Management is an international, peerreviewed journal of clinical therapeutics and risk management, focusing on concise rapid reporting of clinical studies in all therapeutic areas, outcomes, safety, and programs for the effective, safe, and sustained use of medicines. This journal is indexed on PubMed Central, CAS,
EMBase, Scopus and the Elsevier Bibliographic databases. The manuscript management system is completely online and includes a very quick and fair peer-review system, which is all easy to use. Visit http://www.dovepress.com/testimonials.php to read real quotes from published authors.

Submit your manuscript here: http://www.dovepress.com/therapeutics-and-clinical-risk-management-journal 